\title{
Factors Impacting the Interest Rate Derivatives Usage in Indian Commercial Banks
}

\author{
Dilip Kumar \\ Indian Institute of Management Kashipur, Kashipur, India \\ Email: dksic212@gmail.com, dilip.kumar@iimkashipur.ac.in
}

How to cite this paper: Kumar, D. (2017) Factors Impacting the Interest Rate Derivatives Usage in Indian Commercial Banks. Theoretical Economics Letters, 7, 596-614. https://doi.org/10.4236/tel.2017.73045

Received: March 17, 2017

Accepted: April 21, 2017

Published: April 24, 2017

Copyright $\odot 2017$ by author and Scientific Research Publishing Inc. This work is licensed under the Creative Commons Attribution International License (CC BY 4.0).

http://creativecommons.org/licenses/by/4.0/

\begin{abstract}
In this paper, we examine the impact of interest rate risk factors on the interest rate derivatives (IRD) usage by commercial banks in India. We focus our analysis during the period 2008-2010. We have taken this period to highlight that during and after global financial crisis, what were the main factors that influence the interest rate derivatives usage by Indian commercial banks. We have used simulation analysis and regression analysis to identify the interest rate risk factors. Using Tobit fixed effect analysis, we are able to provide empirical evidence that interest rate risk drives the derivatives usages by Indian commercial banks. Our results indicate that asset size, the impact of interest rate shock on equity capital are positively related to use of derivatives for hedging as well as trading and interest rate sensitivity factor is negatively related to the use of derivatives for hedging and trading. New generation private banks have relatively large exposure to derivatives for trading purpose.
\end{abstract}

\section{Keywords}

Interest Rate Risk, Banks, Interest Rate Derivatives, Risk Factors, Tobit Fixed Effect Model

\section{Introduction}

Interest rate risk is one of the core risks in banking books that banks have to accept and take the profit out of them. After credit risk, interest rate risk is an important risk that requires crucial attention and mitigation measures. A sudden and significant shock in interest rates can create a significant asset-liability mismatch in banking books and can eat away the major portion of bank's equity capital which in turn can push the bank to the verge of bankruptcy.

The balance sheet approach and interest rate derivatives usage approach are the two major approaches used by banks to mitigate the impact of interest rate fluctuations. The former is linked with the repricing of maturity profiles of in- 
terest rate sensitive assets and liabilities of the bank's balance sheet. The later is linked with hedging the interest rate risk by using interest rate derivatives. Banks generally deals in derivatives for balance sheet management and market making purposes where the bank offers derivatives services to its customers to hedge their risks. As per RBI guidelines, the Indian banks can deal in interest rate derivatives for hedging fixed rate, floating rate or foreign currency assets/liabilities. Interest rate derivatives comprise of interest rate swaps (IRS), forward rate agreements (FRAs), interest rate futures and foreign currency interest rate swaps. On the other hand, Indian banks can also deal in currency derivatives which include instruments like forwards, foreign currency swaps, foreign currency-rupee swaps, cross currency options, and foreign currency-rupee options. Indian banks are having exposure to interest rate derivatives and currency derivatives for both hedging as well as trading purposes. Table 1 gives the summary statistics of interest rate derivatives and currency derivatives used by Indian banks for hedging and trading purpose in March 2010. The average interest rate derivatives used by Indian banks for the trading purpose is about 12 times the interest rate derivatives used for hedging purpose. Also the aggregate interest rate derivatives exposure is about 3 times the aggregate currency derivatives exposure. The comparison of mean and median values clearly presents that large banks are having huge significant exposure in derivatives. Table 2 presents the aggregate values of interest rate derivatives used by Indian commercial banks in 2008, 2009 and 2010. Interest rate derivatives use for hedging is showing an increasing trend but for the trading case, the interest rate derivatives notional exposure first decreases by about $50 \%$ from 2008 to 2009 and increase by about $12 \%$ in 2010 . Also, the PV01 $\times 100$ values for the trading case are showing increasing trend, which can be interpreted as that banks are selling more of long term contracts.

Since July 1999 RBI allowed Scheduled Commercial Banks, Primary Dealers (PDs) and Financial Institutions to use Interest Rate Swaps (IRS) and Forward Rate Agreements (FRAs) to mitigate the impact of interest rate changes on their asset and liability streams through their own asset liability management (ALM) or for market making i.e. risk trading purposes. India is having an active overthe-counter (OTC) interest rate derivatives market. Most of the interest rate derivatives related transactions are done by foreign banks, large private sector and public sector banks. Dealings in derivatives are carried out by the treasury of

Table 1. Summary statistics of interest rate derivatives and currency derivatives used by banks for hedging as well as trading purpose.

\begin{tabular}{|c|c|c|c|c|c|c|c|c|}
\hline & \multicolumn{4}{|c|}{ Interest rate Derivatives } & \multicolumn{4}{|c|}{ Currency derivatives } \\
\hline & Mean & Median & Total & Number of Banks & Mean & Median & Total & Number of Banks \\
\hline Trading & $45,927.17$ & 9599.36 & $872,616.20$ & 19 & $14,032.81$ & 3955.58 & $252,590.63$ & 18 \\
\hline Hedging & 3832.61 & 500.00 & $88,149.97$ & 23 & 3683.84 & 657.91 & $81,044.51$ & 22 \\
\hline Trading/TA & 0.307 & 0.059 & 0.232 & 19 & 0.089 & 0.067 & 0.015 & 18 \\
\hline
\end{tabular}

Notes: Trading includes the banks using derivatives for trading purpose. Hedging includes the banks using derivatives for hedging purpose. Trading/TA measures the ratio of derivatives exposure for the trading purpose to the total asset (measured for the individual bank). Similarly, Hedging/TA measures the ratio of derivatives exposure for hedging purpose to the total asset. Source: Bank's annual reports and author's computation. 
Table 2. Aggregate value of interest rate derivatives used for hedging and trading.

\begin{tabular}{|c|c|c|c|c|c|c|}
\hline & 2010 & $\mathbf{N}$ & 2009 & $\mathbf{N}$ & 2008 & $\mathbf{N}$ \\
\hline \multicolumn{7}{|c|}{ Total Interest Rate Derivatives Exposure (Notional amount) } \\
\hline Hedging & $88,149.97$ & 23 & $87,425.58$ & 26 & $82,795.45$ & 25 \\
\hline Trading & $872,616.20$ & 19 & $780,150.44$ & 21 & $1,489,976.29$ & 19 \\
\hline \multicolumn{7}{|c|}{ Likely impact of $1 \%$ change in interest rate $(\mathrm{PV} 01 \times 100)$} \\
\hline Hedging & 3189.00 & 23 & 1258.62 & 26 & 1504.76 & 25 \\
\hline Trading & 834.87 & 19 & 322.64 & 21 & 331.06 & 19 \\
\hline \multicolumn{7}{|c|}{ Maximum likely impact of $1 \%$ change in interest rate $(\mathrm{PV} 01 \times 100)$} \\
\hline Hedging & 1768.23 & 23 & -355.54 & 26 & 96.41 & 25 \\
\hline Trading & 929.43 & 19 & 789.73 & 21 & 535.41 & 19 \\
\hline \multicolumn{7}{|c|}{ Minimum likely impact of $1 \%$ change in interest rate $(\mathrm{PV} 01 \times 100)$} \\
\hline Hedging & 2089.17 & 23 & -778.79 & 26 & -572.16 & 25 \\
\hline Trading & 328.25 & 19 & 85.54 & 21 & 87.08 & 19 \\
\hline
\end{tabular}

Source: Bank's annual reports and author's computation.

the bank. Treasury of the bank undertakes the duties of entering derivatives transaction and managing confirmation, settlement, accounting, risk monitoring and reporting with respect to various internal and regulatory guidelines ${ }^{1}$. Risk monitoring of the derivatives portfolio is done on daily basis in banks. Banks generally use daily Value-at-risk (VaR) approach and relevant option Greeks to measure and monitor risks.

Basel recommendations on derivatives usage by banks are based on two main themes. The first theme deals with disclosing a meaningful summary of information related to derivatives exposure ${ }^{2}$ and risks in both qualitative and quantitative form and illustrates how these activities impact their earning profile. The second theme deals with disclosing information produced by internal risk measurement and management system regarding derivatives exposure $[1]^{2}$. Basel also recommends a three-step process for interest rate risk management. It starts with the approval of overall risk policy and the principles of managing interest rate risk by the board of directors of the institution. Next, the senior management has to frame policies, procedures, and tools to monitor, measure and limit the interest rate risk. The last step is related to the successful implementation in all operative units of the institution. For capturing and quantifying the interest rate risk appropriately, the Basel Committee of Banking Supervision has divided the interest rate risk into four parts $[2]^{3,4}$ : Repricing risk, Yield curve risk, basis risk, optionality risk.

Repricing risk is the risk of the difference in maturity pattern of assets, liabilities and off-balance sheet positions. Gap analysis and Duration analysis can be used to quantify re-pricing risk. Yield curve risk is the risk of change of shape

${ }^{1}$ Bank's annual reports.

${ }^{2}$ Here derivatives exposures include all interest rates, currency and credit derivatives used by banks.

${ }^{3}$ Basel Committee on Banking Supervision, 1999. Recommendation for Public Disclosure of Trading and Derivatives Activities of Banks and Securities Firms. Bank for International Settlements.

${ }^{4}$ Basel Committee on Banking Supervision, 2001." Principles for the management and supervision of interest rate risk". Bank for International Settlements. 
and slope of the yield curve. Its management is linked with revaluing the bank's balance sheet under different yield curve scenario. Basis risk is due to the imperfect correlation between the interest rate paid on liability and interest rate earned on asset i.e. due to the imperfect correlation between the yield curve linked with asset and liability of banks. Its management is associated with discounting different products with respect to the yield curve they are linked. Optionality risk arises due to the embedded option linked with banking products. For example: in the case of saving bank accounts, the depositor has the option to withdraw money anytime from his account.

This paper attempts to test the important interest rate risk factors as possible determinants of interest rate derivatives usage for both hedging and trading purposes in banks. The first and second part of the analysis deals with the extraction of interest rate risk factors from raw data. This will use two-factor regression analysis ${ }^{5}$ and simulation analysis ${ }^{6}$. The third part uses these two interest rate risk factors and variables representing bank's characteristics as possible determinants of interest rate derivatives usages by banks. Our results indicate that the interest rate risk factors are significantly impacting the use of interest rate derivatives by banks.

The remainder of the paper is organized as follows. Section 2 reviews the literature and includes the hypothesis, section 3 describes the data, variables, and sources of data used in this study, Section 4 describes the econometric methodology and empirical results and discusses the main findings of our study. Section 5 presents conclusions.

\section{Literature Review}

Flannery \& James [3] investigate the impact of the interest rate changes on common stock returns and maturity composition of 67 actively traded commercial banks and stock savings \& loan association's (S \& Ls) for a period 19761981 and find that fluctuations in interest rate significantly impacts the maturity composition of a firm's net nominal asset holding. Booth \& Officer [4] examine the impact of expected interest rate (3-months and 6-months T-Bill rate) sensitivity on the equity returns of 66 banks and holding companies stocks relative to stocks of 66 non-financial firms during the period 1969-1976 and conclude that there is significant impact of random changes of short-term interest rates on returns of banking stocks and bank holding companies stocks. Choi, Elyasiani \& Kopecky [5] consider both interest rate (monthly average of daily returns on 3 months T-Bill) and exchange rate (trade-weighted multilateral foreign exchange value of the dollar against a basket of currencies) risk factors and study their impact on the sensitivity of 48 US banking institutions stock returns for a period from January 1975 to December 1987 using multifactor index model. To remove multicollinearity, Choi, Elyasiani \& Kopecky [5] use standard orthogonalization method. Results indicate that the negative significant impact of the exchange

${ }^{5}$ The dependent variable is individual banks returns and independent variables are market index returns and interest rate returns.

${ }^{6}$ Historical simulation method is used to find the impact of worst case scenario on equity capital of banks. 
rate (innovations) on bank stock returns for a period prior to October 1979 and positive significant impact for a period thereafter. Shanker [6] empirically investigate the impact of the use of interest rate derivatives on the interest rate risk of the commercial banks by using weekly stock returns and stock market returns during the period 1986-1993 and find that use of derivatives by banks are significantly reducing the interest rate risks of the banks. Patnaik \& Shah [7] proposed a two-step process to study the interest rate risk of the major banks of India for a period from $01 / 04 / 2000$ to $31 / 03 / 2002$ and find that Indian banks are significantly sensitive towards change in interest rates by using both accounting as well as market data. The first step consists of estimating the impact of interest rate shock (of 320 bps) on equity capital of banks. The second step consists of measuring the sensitivity of bank stock prices to the changes in interest rates. Results show that most of the banks (33 of 42 banks) can gain or lose around $25 \%$ of the capital due to 320 bps move in the yield curve. Carter, Simpson \& Tandon [8] investigated the effect of managerial incentives on the use of interest-rate derivatives by 279 U.S. bank holding companies for a period 1996-2000 and find the significant importance of managerial incentives (which is directly linked to the profitability of the bank) on the usage of interest rate derivatives. Purnanandam [9] investigate the impact of bank characteristics and macroeconomic shocks on the interest rate risk management behavior of commercial banks by using a data panel of 8000 banks during the period 1980-2003 and find a significant impact of bank characteristics on derivatives usage volume. Nachane \& Ghosh [10] investigated the determinants of off-balance sheet activities in the Indian banking sector by using data of 90 banks during the period 1996-2004 and concluded that the bank-specific factors, regulatory factors, and general macroeconomic conditions significantly impact the off-balance items. Saha, Subramanian, Basu \& Mishra [11] propose a simulation-based driver-driven approach by using weekly data of 45 different interest rate series and rate sensitive gap data of 11 Indian banks to estimate the impact of interest rate volatility on the networth of Indian banks for a period from 2002 to 2004 and find significant interest rate risk in banking books due to duration mismatch.

In this study, we are looking for two additional factors (Interest rate risk factors) that impacted the interest rate derivatives usage by Indian banks during and after global financial crisis. We have documented in this paper the way to extract these two interest rate risk factors and analyze their impact on derivatives usage.

\section{Data \& Data Sources}

The sample under study uses data on 39 Indian commercial banks ${ }^{7}$ listed on In-

\footnotetext{
${ }^{7}$ Out of 46 listed banks (Source: Prowess), Hindustan Mercantile Bank Ltd. merged with United Bank of India in 1973. Kerala based Nedungadi Bank Ltd. merged with Punjab National Bank in 2003 and that time the shares of Nedungadi Bank Ltd. was having zero value, so, the shareholders of Nedungadi Bank Ltd. did not receive any payment. Also, Bank of Punjab merged with Centurion Bank in 2005 forming single entity Centurion Bank of Punjab. In 2008, HDFC Bank acquired Centurion Bank of Punjab. So, Bank of Punjab and Centurion Bank of Punjab have been excluded from the study. In 2004, IDBI Bank Ltd. merged with IDBI Bank as IDBI Bank Ltd. So IDBI Bank is not taken under study. Also in 2006, United Western Bank Ltd. merged with IDBI Bank Ltd. and come out as a single bank IDBI Bank Ltd. Hence, United Western Bank Ltd. is also not taken under study. United Bank of India is not included in study because the bank is listed at the end of Feb 2010 and sufficient data is not available for study. Hence total of 7 commercial banks have been excluded from total of 46 listed banks and forming a sample of 39 banks.
} 
dian stock exchanges (National Stock Exchange (NSE) and Bombay Stock Exchange (BSE)). The dataset is divided into three categories: The first category refers to Interest rate derivatives exposure data and bank characteristics data, the second category refers to accounting data for simulation analysis and the third category refers to the market data (stock prices and bond prices data) of all listed banks under study.

The data for the first category includes information on interest rate derivatives usage and have been acquired from annual reports of all banks under study for 2008, 2009 and 2010. Data has been categorized on the basis of usage of derivatives i.e. hedging, hedging and trading and no usage. The annual data on bank characteristics ${ }^{8}$ has been taken from PROWESS (CMIE database) for the period from 2008 to 2010. The CMIE database is also known as Centre for Monitoring Indian Economy which provides data related to business information, economy, financial markets, business enterprises and financial performance of individual companies. The data for the second category includes quarterly information on interest income, interest paid, interest sensitive assets and interest sensitive liabilities $^{9}$ for a period Sept. 2000-March 2010. The data on maturity bucket has been taken from PROWESS (CMIE database) and annual reports of banks for the year 2010. The data for the third category includes monthly information on stock prices of individual banks, S \& P CNX Nifty index value, Bank Nifty index value and the T-bill index value for a period Mar 2005-Mar 2010 with a total of 60 observations. The data on stock prices of individual banks has been acquired from PROWESS (CMIE database) and the data onT-Billindex ${ }^{10}$, S \& P CNX Nifty Index ${ }^{11}$ and Bank Nifty index have been obtained from NSE website (www.nseindia.com).

\section{Methodology \& Results}

We have used a three step approach in this study. In first and second step, we will show the methodology of extracting interest rate risk factors. The third step deals with the use of extracted interest rate risk factors and banks characteristics to observe if interest rate risk factors impact the interest rate derivatives usage.

\subsection{Estimation of Interest Rate Sensitivity (Beta) Factor}

In the first step, we estimate the interest rate sensitivity factor as one proxy for interest rate risk. Table 3 presents the variables definition for the analysis.

The monthly returns of each security have been calculated as follow:

$$
R_{i, t}=\ln \left(\frac{P_{i, t}}{P_{i, t-1}}\right)
$$

where $P_{i, t}$ represents the price of stock $i$ at time $t$ and $P_{i, t-1}$ represents the price of ${ }^{8}$ Size, Liquidity, Credit risk, Capital adequacy ratio, Profitability and Asset structure, Market capitalization.

${ }^{9}$ Interest sensitive assets includes loans and advances, investment, balance with other banks, balance with RBI and interest sensitive liabilities includes deposits, borrowings and interest accrued.

${ }^{10}$ Proxy for interest rate.

${ }^{11}$ Proxy for market. 
Table 3. Variable definitions for the market model.

\begin{tabular}{ccc}
\hline Variable & Definition & Data Source \\
\hline$R_{i, t}$ & $\mathrm{i}^{\text {th }}$ bank stock returns at time $t$ & PROWESS \\
$R_{m, t}$ & Market index returns (CNX Nifty index) at time $t$ & $\underline{\text { www.nseindia.com }}$ \\
$R_{b, t}$ & Interest rate returns at time $t$ & $\underline{\text { www.nseindia.com }}$ \\
$R_{b n, t}$ & Bank nifty index returns at time $t$ & $\underline{\text { www.nseindia.com }}$ \\
$R_{e, t}$ & Equally weighted returns of all banks at time $t^{22}$ & Based on equally weighted calculation \\
\hline
\end{tabular}

stock $i$ at time $t-1$. The return for themarket index $\left(R_{m, t}\right)$ and interest rate index $\left(R_{b, t}\right)$ are found in thesame manner.

The standard market model that can capture the sensitivity of stock returns with respect to fluctuation in market index returns is given by:

$$
R_{i, t}=\alpha_{i}+\beta_{m} R_{m, t}+\varepsilon_{i t}
$$

where

$$
\begin{aligned}
& \alpha_{i}=\text { Constant. } \\
& \beta_{m}=\text { Market index sensitivity factor. } \\
& \varepsilon_{i t}=\text { Error term. }
\end{aligned}
$$

To study the impact of interest rate returns on stock returns, the model in (1) can be modified by adding interest rate return as an additional factor. The modified model is given as:

$$
R_{i, t}=\alpha_{i}+\beta_{m i} R_{m, t}+\beta_{b i} R_{b, t}+\varepsilon_{i t}
$$

where

$\alpha_{i}=$ constant for ith bank.

$\beta_{m i}=$ sensitivity parameter of ith stock return with respect to market return.

$\beta_{b i}=$ sensitivity parameter of ith stock return with respect to interest rate index return ${ }^{13}$.

$\varepsilon_{i t}=$ Residuals for ith stock for the end of time $t$.

To test how banking sector as a whole react to changes in interest rates, we have analyzed the impact of interest rate changes on Bank Nifty index returns and equally weighted returns of all banks under study. The respective regression equations are specified as follows:

$$
\begin{gathered}
R_{b n, t}=\alpha+\beta_{m} R_{m t}+\beta_{b} R_{b t}+\epsilon_{t} \\
R_{e, t}=\alpha+\beta_{m} R_{m t}+\beta_{b} R_{b t}+\epsilon_{t}
\end{gathered}
$$

Table 4 presents the results of market interest rate sensitivity analysis. Results

\footnotetext{
${ }^{12}$ Equally weighted return regression model can help in examining the average impact of interest rate changes on stock returns of the firm. We have performed equally weighted return analysis for all banks as well as for the groups (IRD users for hedging, IRD users for hedging and trading and IRD non-users). If $r_{1}, r_{2}, \cdots, r_{n}$ be the returns of $\mathrm{n}$ banks at certain point of time, then equally weighted return of banks is given by: -
}

$$
R_{e, t}=\frac{r_{1 t}+r_{2 t}+\cdots+r_{n t}}{n}
$$

${ }^{13}$ This is stored as one interest rate risk factor for further analysis. 
Table 4. Empirical estimation of market and interest rate sensitivity (For T-Bills).

\begin{tabular}{cccccc}
\hline \multirow{2}{*}{ Characteristics } & \multicolumn{2}{c}{ Equally Weighted Return Analysis on the basis of Derivatives Usage } \\
\cline { 2 - 6 } & $\begin{array}{c}\text { Equally weighted } \\
\text { returns }\end{array}$ & Bank Nifty Index & Hedging & $\begin{array}{c}\text { Hedging \& } \\
\text { Trading }\end{array}$ & No Use \\
\hline$\alpha_{i}$ & $-0.044^{* *}$ & -0.027 & $-0.043^{*}$ & $-0.035^{*}$ & $-0.056^{* *}$ \\
& $-(2.397)$ & $-(1.389)$ & $-(1.898)$ & $-(1.963)$ & $-(2.479)$ \\
$\beta_{m}$ & $1.266^{* * *}$ & $1.236^{* * *}$ & $1.180^{* * *}$ & $1.272^{* *}$ & $1.316^{* * *}$ \\
& $(16.138)$ & $(14.965)$ & $(11.963)$ & $(16.329)$ & $(13.454)$ \\
$\beta_{b}$ & $6.667^{* *}$ & 4.408 & $6.886^{*}$ & $5.498^{*}$ & $8.292^{*}$ \\
& $(2.157)$ & $(1.354)$ & $(1.772)$ & $(1.791)$ & $(2.151)$ \\
R-Square & 0.820 & 0.797 & 0.715 & 0.824 & 0.761 \\
$\mathrm{~N}$ & 39 Banks & & 8 Banks & 19 Banks & 12 Banks \\
\hline
\end{tabular}

Notes: t-statistics are in parentheses. ${ }^{\star} 10 \%$ Significance level. ${ }^{*} 5 \%$ Significance level. ${ }^{* *} 1 \%$ Significance level.

show that the banks not using interest rate derivatives are positively and significantly impacted by the changes in interest rate returns. Banks using interest rate derivatives are also not immune to the changes in interest rates and showing the positive and less significant relationship. Bank Nifty index consists of 12 banks and out of these 11 banks are using derivatives to mitigate their interest rate risk. Our results indicate that bank nifty index returns are not showing a significant relationship with the changes in interest rates. But the banking sector ${ }^{14}$ as a whole is showing is a significant positive relationship with the changes in interest rates.

\subsection{Estimation of Impact of Interest Rate Shock on Equity Capital of Banks ${ }^{15}$}

The idea behind simulation is to use accounting data to generate different scenarios to find the impact of interest rate changes on bank equity capital. Different scenarios of the yield of funds and cost of funds are generated by using historical accounting data. Table 5 presents the variables used in simulation analysis. The worst case scenario ${ }^{16}$ results and $200 \mathrm{bp}$ shock results are compared with the possible results of June 2010 .

We have used the yield on funds to discount the asset side and cost of fund to discount the liability side of the maturity buckets of banks.

The simulation process includes the computation of the rate of change of yield on funds $\left(\Delta r_{y}\right)$ and rate of change of the cost of funds $\left(\Delta r_{c}\right)$ for all the given scenarios in the study to find the possible next period interest rate changes. We then compute the NPV of assets and liabilities in maturity bucket by discounting the exposure to respective discount rates. We first find NPV of assets and liabilities on March 31, 2010, and we supposed this time as time 0.

\footnotetext{
${ }^{14}$ Equally weighted returns.

${ }^{15}$ Second interest rate risk factor for further analysis.

${ }^{16} 5^{\text {th }}$ percentile result of the simulation analysis.
} 
Table 5. Variable definitions for simulation analysis.

\begin{tabular}{|c|c|c|}
\hline Variable & Definition & Data Source \\
\hline Yield on funds & $\begin{array}{l}\text { Measured by the ratio of interest income to } \\
\text { the rate sensitive assets }\end{array}$ & PROWESS \\
\hline Cost of funds & $\begin{array}{l}\text { Measured by the ratio of interest expense to } \\
\text { the rate sensitive liabilities }\end{array}$ & PROWESS \\
\hline Rate sensitive assets & $\begin{array}{l}\text { Measured by the sum of total loans and } \\
\text { advances, investments, bank balance with } \\
\text { other banks and balance with RBI }{ }^{11}\end{array}$ & PROWESS \\
\hline $\begin{array}{l}\text { Rate sensitive } \\
\text { liabilities }\end{array}$ & $\begin{array}{l}\text { Measured by the sum of total deposits, } \\
\text { borrowings and interest accrued }\end{array}$ & PROWESS \\
\hline GAP & $\begin{array}{l}\text { Measured as difference between NPV of } \\
\text { assets and liabilities }\end{array}$ & $\begin{array}{l}\text { Based on calculation with } \\
\text { respect to maturity } \\
\text { bucket exposure }\end{array}$ \\
\hline$\Delta \mathrm{E}$ & $\begin{array}{l}\text { Unexpected impact on equity, measured by } \\
\text { the difference between } \operatorname{GAP}(\Delta) \text { (GAP due to } \\
\text { worst case scenario) and GAP }(0) \text { (GAP due } \\
\text { to present expected yield on fund and cost } \\
\text { on fund) }\end{array}$ & Based on calculation \\
\hline$\Delta \mathrm{E} / \mathrm{BE}$ & $\begin{array}{l}\text { Ratio of unexpected impact on equity to the } \\
\text { book value of equity }\end{array}$ & Based on calculation \\
\hline$\Delta \mathrm{E} / \mathrm{MVE}$ & $\begin{array}{l}\text { Ratio of unexpected impact on equity to the } \\
\text { market value of equity }\end{array}$ & Based on calculation \\
\hline$\Delta \mathrm{E} / \mathrm{TA}$ & $\begin{array}{l}\text { Ratio of unexpected impact on equity to the } \\
\text { total asset }\end{array}$ & Based on calculation \\
\hline
\end{tabular}

$$
\begin{aligned}
& \text { NPV of Assets }(0)=\sum_{i=1}^{N} \frac{A_{i}}{\left(1+r_{y}\right)^{t_{i}}} \\
& \text { NPV of Liability }(0)=\sum_{i=1}^{N} \frac{L_{i}}{\left(1+r_{c}\right)^{t_{i}}}
\end{aligned}
$$

where $r_{y}$ and $r_{c}$ are the present yield on funds and cost of funds. $A_{i}$ and $L_{i}$ are the asset and liability side exposure for different time periods in maturity bucket.

The mismatch between asset and liability is computed as GAP. The GAP at time 0 (31 March 2010) is given by:

$$
\text { GAP }(0)=\text { NPV of Assets }(0)-\text { NPV of Liability }(0)
$$

We now compute NPV of asset and Liability for next quarter by using 36 scenarios of the rate of change of interest rates for asset and liability side of maturity bucket.

$$
\begin{gathered}
\text { NPV of Assets }(\Delta)=\sum_{i=1}^{N} \frac{A_{i}}{\left(1+\Delta r_{y}+r_{y}\right)^{t_{i}}} \\
\text { NPV of Liability }(\Delta)=\sum_{i=1}^{N} \frac{L_{i}}{\left(1+\Delta r_{c}+r_{c}\right)^{t_{i}}}
\end{gathered}
$$

where $\Delta r_{y}$ and $\Delta r_{c}$ are the possible rates of change of interest rates for yield on funds and cost of funds. The mismatch between asset and liability of maturity 
Table 6. Results of simulation analysis.

\begin{tabular}{|c|c|c|c|c|c|c|c|c|c|}
\hline \multirow[b]{2}{*}{ Ratios } & \multirow{2}{*}{$\begin{array}{c}\text { Characteristic } \\
\text { s }\end{array}$} & \multicolumn{2}{|c|}{ All Banks } & \multicolumn{2}{|c|}{ Hedging } & \multicolumn{2}{|c|}{ Hedging \& Trading } & \multicolumn{2}{|c|}{ No use } \\
\hline & & $\begin{array}{l}(+2 \%) \\
\text { Shock }\end{array}$ & $\begin{array}{c}5^{\text {th }} \\
\text { Percentile }\end{array}$ & $\begin{array}{l}(+2 \%) \\
\text { Shock }\end{array}$ & $\begin{array}{c}5^{\text {th }} \\
\text { Percentile }\end{array}$ & $(+2 \%)$ Shock & $\begin{array}{c}5^{\text {th }} \\
\text { Percentile }\end{array}$ & $(+2 \%)$ Shock & $\begin{array}{c}5^{\text {th }} \\
\text { Percentile }\end{array}$ \\
\hline \multirow{4}{*}{$\Delta \mathrm{E} / \mathrm{BVE}$} & Mean & $-11.82 \%$ & $-3.64 \%$ & $-12.99 \%$ & $-4.12 \%$ & $-8.49 \%$ & $-2.94 \%$ & $-16.32 \%$ & $-4.44 \%$ \\
\hline & Median & $-7.90 \%$ & $-3.13 \%$ & $-11.55 \%$ & $-3.41 \%$ & $-5.86 \%$ & $-2.59 \%$ & $-10.17 \%$ & $-4.13 \%$ \\
\hline & Q1 & $-20.21 \%$ & $-4.69 \%$ & $-30.67 \%$ & $-5.97 \%$ & $-10.85 \%$ & $-3.20 \%$ & $-27.04 \%$ & $-5.06 \%$ \\
\hline & Q3 & $-4.34 \%$ & $-2.46 \%$ & $-1.07 \%$ & $-2.83 \%$ & $-4.48 \%$ & $-2.22 \%$ & $-5.34 \%$ & $-3.17 \%$ \\
\hline \multirow{4}{*}{$\Delta \mathrm{E} / \mathrm{MVE}$} & Mean & $-10.71 \%$ & $-3.07 \%$ & $-12.03 \%$ & $-3.85 \%$ & $-7.14 \%$ & $-2.14 \%$ & $-15.475 \%$ & $-4.03 \%$ \\
\hline & Median & $-5.76 \%$ & $-2.54 \%$ & $-12.34 \%$ & $-3.25 \%$ & $-3.80 \%$ & $-1.80 \%$ & $-8.292 \%$ & $-3.08 \%$ \\
\hline & Q1 & $-18.32 \%$ & $-3.92 \%$ & $-24.21 \%$ & $-5.17 \%$ & $-8.44 \%$ & $-2.25 \%$ & $-20.657 \%$ & $-4.22 \%$ \\
\hline & Q3 & $-1.90 \%$ & $-1.77 \%$ & $-0.51 \%$ & $-2.52 \%$ & $-1.68 \%$ & $-0.97 \%$ & $-5.309 \%$ & $-2.68 \%$ \\
\hline \multirow{4}{*}{$\Delta \mathrm{E} / \mathrm{A}$} & Mean & $-0.61 \%$ & $-0.19 \%$ & $-0.54 \%$ & $-0.18 \%$ & $-0.51 \%$ & $-0.18 \%$ & $-0.81 \%$ & $-0.22 \%$ \\
\hline & Median & $-0.56 \%$ & $-0.18 \%$ & $-0.57 \%$ & $-0.17 \%$ & $-0.44 \%$ & $-0.18 \%$ & $-0.65 \%$ & $-0.22 \%$ \\
\hline & Q1 & $-1.14 \%$ & $-0.23 \%$ & $-1.22 \%$ & $-0.21 \%$ & $-0.74 \%$ & $-0.22 \%$ & $-1.40 \%$ & $-0.27 \%$ \\
\hline & Q3 & $-0.27 \%$ & $-0.14 \%$ & $-0.05 \%$ & $-0.16 \%$ & $-0.30 \%$ & $-0.14 \%$ & $-0.30 \%$ & $-0.17 \%$ \\
\hline $\begin{array}{l}\text { Number } \\
\text { of Banks }\end{array}$ & & \multicolumn{2}{|c|}{39} & \multicolumn{2}{|c|}{8} & \multicolumn{2}{|c|}{19} & \multicolumn{2}{|l|}{12} \\
\hline
\end{tabular}

bucket for next quarter is measured as:

$$
\operatorname{GAP}(\Delta)=\operatorname{NPV} \text { of Assets }(\Delta)-\operatorname{NPV} \text { of Liability }(\Delta)
$$

$\mathrm{GAP}(0)$ is the mismatch that bank is aware of but the bank is uncertain about next quarter $\operatorname{GAP}(\Delta)$. We have taken $\operatorname{GAP}(\Delta)$ as the $5^{\text {th }}$ percentile worst case scenario result from simulation analysis. Hence the possible worst impact on equity capital of the bank is given by:

$$
\Delta E=\mathrm{GAP}(\Delta)-\mathrm{GAP}(0)
$$

A shock of $200 \mathrm{bp}$ is given to present yield on funds and cost of funds to find the impact of such shock on equity capital of bank by the same procedure as explained above. Table 6 reports the results acquired by simulation analysis. Results show that banks not using derivatives can lose more capital than the banks using interest rate derivatives for hedging and trading purpose. On average, banks can lose upto $10 \%$ of the equity capital for a 200 bp shock with respect to about $3 \%$ loss as per worst case historical scenarios. Banks using interest rate derivatives for hedging purpose can lose about $12 \%$ of their equity capital for a 200 bp shock with respect to about $3.85 \%$ for $5^{\text {th }}$ percentile worst case scenarios. Banks using interest rate derivatives for hedging and trading will lose less on average. But the banks not using any interest rate derivatives can lose on average about $15.5 \%$ of equity capital for the $200 \mathrm{bp}$ shock to interest rates with respect to $5^{\text {th }}$ percentile worst case scenario loss of about $4 \%$. The simulation analysis reports the presence of asset liability mismatch in the banking book. 
Table 7. Variable ${ }^{17}$ definitions for the Tobit model.

\begin{tabular}{|c|c|c|}
\hline Variable & Definition & Data Source \\
\hline IRD_PV_HEDGE & Likely impact of $1 \%$ change in interest rate on hedging interest rate derivatives & Bank's annual reports \\
\hline IRD_PV_TOTAL & Likely impact of $1 \%$ change in interest rates on total interest rate derivatives & Bank's annual reports \\
\hline IRD_HEDGE & Interest rate derivatives notional exposure by banks for hedging purpose & Bank's annual reports \\
\hline IRD_TOTAL & $\begin{array}{l}\text { Interest rate derivatives notional exposure by banks for both hedging and trading } \\
\text { purpose. }\end{array}$ & Bank's annual reports \\
\hline D_2008 & Dummy equals to 1 , if year is 2008 , otherwise, equals to 0 & Based on time \\
\hline D_2009 & Dummy equals to 1 , if year is 2009 , otherwise, equals to 0 & Based on time \\
\hline SIZE & Bank size, measured by natural logarithm of total asset of the bank & PROWESS \\
\hline LIQUID & Bank liquidity, measured by the ratio of liquid assets to total assets & PROWESS \\
\hline CREDIT_RISK & $\begin{array}{l}\text { Proxy for credit risk in a bank, measured by the ratio of non-performing asset (NPA) to } \\
\text { the total loans and advances. }\end{array}$ & PROWESS \\
\hline CAR & Capital adequacy ratio & PROWESS \\
\hline PROFITABILITY & Measured by the ratio of profit after tax (PAT) to total asset & PROWESS \\
\hline ASSET_STRUCT_1 & $\begin{array}{l}\text { Asset structure, measured by the ratio of total loans and advances to the market value of } \\
\text { equity }\end{array}$ & PROWESS \\
\hline ASSET_STRUCT_2 & Asset structure, measured by the ratio of total deposits to the market value of equity & PROWESS \\
\hline MARKET_CAP & Measured as a ratio of market value of equity to total asset & PROWESS \\
\hline INT_RISK_1 & $\begin{array}{l}\text { Interest rate risk, measured by the beta sensitivity of the interest rates (derived from } \\
\text { regression analysis (Dependent variable is bank's returns and independent variables are } \\
\text { market returns and interest rate returns) }\end{array}$ & Based on regression results \\
\hline INT_RISK_2 & Interest rate risk, measured by $\Delta \mathrm{E}$ & Based on simulation results \\
\hline
\end{tabular}

\subsection{Determinants of Derivatives Usage}

Table 7 presents the list of variables with definition and data source used for final analysis. We have used fixed effect Tobit regression model ${ }^{18}$ for the motivations for derivatives usage. Being a censored regression model, Tobit model can be used in cases where the dependent variable is partially observed. Some banks in the sample are not using any derivatives, so Tobit regression model is one good option for our analysis.

The general Tobit model is structured as follows:

$$
y_{i}^{*}=x_{i}^{\prime} \beta+\sigma \varepsilon_{i}
$$

where $x_{i}^{\prime}$ being a matrix of explanatory variables where each column represent one explanatory variable. $\beta$ is a vector of parameters to be estimated. $\sigma$ is a scale parameter. The scale parameter $\sigma$ is identified in censored regression models and is estimated along with $\beta$.

In Tobit model, the observed data are given by:

$$
y_{i}= \begin{cases}0 & \text { if } y_{i}^{*} \leq 0 \\ y_{i}^{*} & \text { if } y_{i}^{*}>0\end{cases}
$$

\footnotetext{
${ }^{17}$ Choice of variables also considers multicollinearity issue.

${ }^{18}$ Here we have pooled the annual data of years 2008, 2009 and 2010.
} 
Table 8. Summary statistics of interest rate derivative users (hedging and hedging \& trading) vs. non-users.

\begin{tabular}{ccccccc}
\hline & \multicolumn{2}{c}{ Hedging } & \multicolumn{2}{c}{ Hedging \& Trading } & \multicolumn{2}{c}{ No use } \\
\cline { 2 - 7 } & Mean & Median & Mean & Median & Mean & Median \\
\hline SIZE & 11.331 & 11.414 & 11.388 & 11.704 & 10.245 & 10.550 \\
LIQUID & 0.083 & 0.083 & 0.093 & 0.093 & 0.104 & 0.103 \\
CREDIT_RISK & 0.009 & 0.009 & 0.010 & 0.006 & 0.009 & 0.009 \\
CAR & 12.214 & 12.145 & 14.055 & 13.080 & 12.399 & 12.355 \\
PROFITABILITY & 2.569 & 2.283 & 2.394 & 2.288 & 2.767 & 2.495 \\
ASSET_STRUCT_1 & 18.923 & 14.710 & 9.336 & 7.517 & 13.804 & 12.543 \\
ASSET_STRUCT_2 & 27.602 & 22.605 & 12.710 & 10.389 & 20.212 & 17.321 \\
MARKET_CAP & 0.044 & 0.039 & 0.136 & 0.080 & 0.055 & 0.050 \\
INT_RISK_1 & 5.466 & 4.635 & 5.118 & 6.295 & 8.531 & 7.192 \\
INT_RISK_2 & -187.820 & -118.760 & -306.578 & -260.020 & -110.853 & -73.840 \\
Number of Banks & & 8 & & & & \\
\hline
\end{tabular}

Hence the data is left censored at 0 . The $\beta$ parameters are estimated using maximum likelihood estimation method.

We examine the possible factors motivating the notional interest rate derivatives exposure using the following general model:

$$
\text { IRD }=f\left(\text { control variables }{ }^{19},\right. \text { interest rate risk variables) }
$$

Table 8 presents the summary statistics of all control variables and interest rate risk variables. To capture time effect, we have used two-time dummies for the year 2008 (D_2008) and 2009 (D_2009). We use three different model specifications for both hedging and total interest rate derivatives usage $\mathrm{e}^{20}$.

For motivation of interest rate derivatives usage for hedging purpose, the dependent variable for all models is IRD_HEDGE. In model 1, IRD_HEDGE is regressed against control variables capturing bank's characteristics and one interest rate risk variable (INT_RISK_1). In model 2, instead of INT_RISK_1, we try to capture the impact of second interest rate risk variable INT_RISK_2. In model 3, combined impact of both interest rate risk variables (INT_RISK_1 and INT_RISK_2) are examined.

Model $1^{21}$ specification is given by:

$$
\begin{aligned}
& \text { IRD_HEDGE }_{i, t}=\beta_{0}+\beta_{1} \mathrm{D}_{2} 2008_{t}+\beta_{2} \mathrm{D}_{-} 2009_{t}+\beta_{3} \mathrm{SIZE}_{i, t}+\beta_{4} \mathrm{LIQUID}_{i, t} \\
& +\beta_{5} \text { CREDIT_RISK }_{i, t}+\beta_{6} \mathrm{CAR}_{i, t}+\beta_{7} \text { PROFITABILITY }_{i, t} \\
& +\beta_{8} \text { ASSET_STRUCT_1 } 1_{i, t}+\beta_{9} \text { ASSET_STRUCT_ } 2_{i, t} \\
& +\beta_{10} \text { MARKET_CAP } i+\beta_{11} \text { INT_RISK_ } 1_{i}+\varepsilon_{i, t}
\end{aligned}
$$

\footnotetext{
${ }^{19}$ These are the bank characteristics variables like SIZE, LIQUID, CREDIT_RISK, CAR, PROFITABILITY, ASSET_STRUCT_1, ASSET_STRUCT_2.

${ }^{20}$ For hedging derivatives case, the dependent variable is IRD_HEDGE and for total derivatives case, the dependent variable is IRD_TOTAL.

${ }^{21}$ Censored tobit fixed effect regression model.
} 
Model 2 specification is given by:

$$
\begin{aligned}
& \text { IRD_HEDGE }_{i, t}=\beta_{0}+\beta_{1} \text { D_2008 }_{t}+\beta_{2} \text { D_2009 }_{t}+\beta_{3} \text { SIZE }_{i, t}+\beta_{4} \text { LIQUID }_{i, t} \\
& +\beta_{5} \text { CREDIT_RISK }_{i, t}+\beta_{6} \text { CAR }_{i, t}+\beta_{7} \text { PROFITABILITY }_{i, t} \\
& +\beta_{8} \text { ASSET_STRUCT_1 } 1_{i, t}+\beta_{9} \text { ASSET_STRUCT_ } 2_{i, t} \\
& +\beta_{10} \text { MARKET_CAP }{ }_{i}+\beta_{12} \text { INT_RISK_} 2_{i}+\varepsilon_{i, t}
\end{aligned}
$$

Model 3 specification is given by:

$$
\begin{aligned}
& \text { IRD_HEDGE }_{i, t}=\beta_{0}+\beta_{1} \mathrm{D} \_2008_{t}+\beta_{2} \mathrm{D} \_2009_{t}+\beta_{3} \mathrm{SIZE}_{i, t}+\beta_{4} \mathrm{LIQUID}_{i, t} \\
& +\beta_{5} \text { CREDIT_RISK }_{i, t}+\beta_{6} \text { CAR }_{i, t}+\beta_{7} \text { PROFITABILITY }_{i, t} \\
& +\beta_{8} \text { ASSET_STRUCT_ } 1_{i, t}+\beta_{9} \text { ASSET_STRUCT_ } 2_{i, t} \\
& +\beta_{10} \text { MARKET_CAP }{ }_{i}+\beta_{11} \text { INT_RISK_ } 1_{i} \\
& +\beta_{12} \text { INT_RISK_2 } i+\varepsilon_{i, t}
\end{aligned}
$$

Similarly for the motivation for total interest rate derivatives usage, the dependent variable for all models is IRD_TOTAL. Same explanatory variables ${ }^{22}$ are taken for total derivatives regression analysis.

Model 1 specification is given by:

$$
\begin{aligned}
& \mathrm{IRD}_{-} \mathrm{TOTAL}_{i, t}=\beta_{0}+\beta_{1}{\mathrm{D} \_2008_{t}}+\beta_{2} \mathrm{D}_{-} 2009_{t}+\beta_{3} \mathrm{SIZE}_{i, t}+\beta_{4} \mathrm{LIQUID}_{i, t} \\
& +\beta_{5} \text { CREDIT_RISK }_{i, t}+\beta_{6} \text { CAR }_{i, t}+\beta_{7} \text { PROFITABILITY }_{i, t} \\
& +\beta_{8} \text { ASSET_STRUCT_ } 1_{i, t}+\beta_{9} \text { ASSET_STRUCT_ } 2_{i, t} \\
& +\beta_{10} \text { MARKET_CAP }_{i}+\beta_{11} \text { INT_RISK_}_{-}+\varepsilon_{i, t}
\end{aligned}
$$

Model 2 specification is given by:

$$
\begin{aligned}
& \mathrm{IRD} \_T O T A L_{i, t}=\beta_{0}+\beta_{1}{\mathrm{D} \_2008_{t}}+\beta_{2} \mathrm{D} \_2009_{t}+\beta_{3} \mathrm{SIZE}_{i, t}+\beta_{4} \mathrm{LIQUID}_{i, t} \\
& +\beta_{5} \text { CREDIT_RISK }_{i, t}+\beta_{6} \text { CAR }_{i, t}+\beta_{7} \text { PROFITABILITY }_{i, t} \\
& +\beta_{8} \text { ASSET_STRUCT_1 } 1_{i, t}+\beta_{9} \text { ASSET_STRUCT_ } 2_{i, t} \\
& +\beta_{10} \text { MARKET_CAP }+\beta_{12} \text { INT_RISK_ } 2_{i}+\varepsilon_{i, t}
\end{aligned}
$$

Model 3 specification is given by:

$$
\begin{aligned}
& \text { IRD_TOTAL }_{i, t}=\beta_{0}+\beta_{1} \mathrm{D} \_2008_{t}+\beta_{2} \mathrm{D} \_2009_{t}+\beta_{3} \mathrm{SIZE}_{i, t}+\beta_{4} \text { LIQUID }_{i, t} \\
& +\beta_{5} \text { CREDIT_RISK }_{i, t}+\beta_{6} \text { CAR }_{i, t}+\beta_{7} \text { PROFITABILITY }_{i, t} \\
& +\beta_{8} \text { ASSET_STRUCT_ } 1_{i, t}+\beta_{9} \text { ASSET_STRUCT_ } 2_{i, t} \\
& +\beta_{10} \text { MARKET_CAP } i+\beta_{11} \text { INT_RISK_1 } \\
& +\beta_{12} \text { INT_RISK_2 } 2_{i}+\varepsilon_{i, t}
\end{aligned}
$$

Table 9 reports the results of fixed effect tobit analysis for the effects of bank characteristics and interest rate risk on banks' participation in interest rate derivatives instruments for hedging and hedging and trading for different models specifications. The Chi-square statistics report the goodness of fit of models. Researches by Shanker [6], Mian [12], Colquitt and Hoyt [13], Sinkey and Carter [14], Cummins et al. [15] and Shiu and Moles [16] report the positive relationship between the size of bank and interest rate derivatives usage. The significant positive coefficient of variable SIZE for all models supports the fact that the use of interest rate derivatives is dominated by large banks, especially for trading

${ }^{22}$ The explanatory variables used in Equations (1)-(3). 
Table 9. Empirical estimation of determinants of interest rate derivatives usage (Notional Value): using tobit fixed effects regression model.

\begin{tabular}{|c|c|c|c|c|c|c|}
\hline & \multicolumn{3}{|c|}{ Hedging } & \multicolumn{3}{|c|}{ Hedging and Trading } \\
\hline & Model 1 & Model 2 & Model 3 & Model 1 & Model 2 & Model 3 \\
\hline \multirow[t]{2}{*}{ Constant } & $-0.165^{\star * *}$ & $-0.245^{\star * *}$ & $-0.236^{\star * *}$ & $-1.585^{\star * *}$ & $-2.754^{\star * *}$ & $-2.774^{* * *}$ \\
\hline & $-(5.020)$ & $-(5.571)$ & $-(5.596)$ & $-(3.137)$ & $-(4.201)$ & $-(4.213)$ \\
\hline \multirow[t]{2}{*}{ 2008_DUM } & $0.013^{* *}$ & $0.016^{* * *}$ & $0.016^{* * *}$ & $0.357^{* * *}$ & $0.404^{* * *}$ & $0.409^{* * *}$ \\
\hline & $(2.282)$ & $(2.709)$ & $(2.832)$ & $(3.800)$ & $(4.288)$ & $(4.357)$ \\
\hline \multirow[t]{2}{*}{ 2009_DUM } & $0.014^{\star *}$ & $0.019^{* * *}$ & $0.019^{* * *}$ & $0.398^{* * *}$ & $0.468^{\star * *}$ & $0.471^{* * *}$ \\
\hline & $(2.317)$ & $(2.887)$ & $(3.020)$ & $(3.864)$ & $(4.486)$ & $(4.524)$ \\
\hline \multirow[t]{2}{*}{ SIZE } & $0.014^{\star * *}$ & $0.022^{\star * *}$ & $0.023^{\star * *}$ & $0.165^{\star * *}$ & $0.291^{\star * *}$ & $0.301^{\star * *}$ \\
\hline & $(6.137)$ & $(5.632)$ & $(5.821)$ & $(4.289)$ & $(4.703)$ & $(4.772)$ \\
\hline \multirow[t]{2}{*}{ LIQUID } & 0.069 & 0.070 & 0.050 & $-5.892^{\star \star \star}$ & $-6.189^{* * *}$ & $-6.268^{\star * *}$ \\
\hline & $(0.610)$ & $(0.601)$ & $(0.441)$ & $-(2.972)$ & $-(3.142)$ & $-(3.180)$ \\
\hline \multirow[t]{2}{*}{ CREDIT_RISK } & -0.079 & 0.077 & 0.072 & $-15.682^{*}$ & $-13.160^{*}$ & -12.842 \\
\hline & $-(0.165)$ & $(0.158)$ & $(0.150)$ & $-(1.955)$ & $-(1.663)$ & $-(1.606)$ \\
\hline \multirow[t]{2}{*}{ CAR } & 0.000 & 0.000 & 0.000 & 0.026 & 0.023 & 0.020 \\
\hline & $(0.140)$ & $(0.116)$ & $-(0.191)$ & $(1.317)$ & $(1.170)$ & $(1.027)$ \\
\hline \multirow[t]{2}{*}{ PROFITABILITY } & -0.889 & $-1.445^{\star}$ & -1.223 & $-34.131^{\star \star}$ & $-40.514^{\star * \star}$ & $-38.874^{* * *}$ \\
\hline & $-(1.057)$ & $-(1.656)$ & $-(1.456)$ & $-(2.544)$ & $-(3.049)$ & $-(2.899)$ \\
\hline \multirow[t]{2}{*}{ ASSET_STRUCT_1 } & 0.001 & 0.001 & 0.001 & -0.020 & -0.025 & -0.026 \\
\hline & $(0.618)$ & $(0.440)$ & $(0.397)$ & $-(0.678)$ & $-(0.875)$ & $-(0.916)$ \\
\hline \multirow[t]{2}{*}{ ASSET_STRUCT_2 } & -0.001 & -0.001 & -0.001 & 0.010 & 0.011 & 0.011 \\
\hline & $-(0.771)$ & $-(0.752)$ & $-(0.723)$ & $(0.552)$ & $(0.579)$ & $(0.624)$ \\
\hline \multirow[t]{2}{*}{ MARKET_CAP } & $0.075^{* * *}$ & $0.074^{* * *}$ & $0.076^{* * *}$ & $4.182^{\star \star \star}$ & $4.149^{* * *}$ & $4.163^{\star \star \star}$ \\
\hline & $(3.137)$ & $(3.045)$ & $(3.210)$ & $(10.506)$ & $(10.678)$ & $(10.704)$ \\
\hline \multirow[t]{2}{*}{ INT_RISK_1 } & $-0.001^{\star \star \star}$ & - & $-0.001^{\star \star \star}$ & -0.008 & - & $-0.010^{\star}$ \\
\hline & $-(2.667)$ & - & $-(2.988)$ & $-(1.452)$ & - & $-(1.777)$ \\
\hline \multirow[t]{2}{*}{ INT_RISK_2 } & - & $3.63 \times 10^{-5 * *}$ & $3.97 \times 10^{-5 * * *}$ & - & $0.001^{* *}$ & $0.001^{* * *}$ \\
\hline & - & $(2.494)$ & $(2.827)$ & - & $(2.661)$ & $(2.854)$ \\
\hline Chi-Square statistics & $69.720^{\star * *}$ & $66.113^{\star * *}$ & $75.822^{\star * *}$ & $222.106^{\star * \star}$ & $234.231^{\star \star *}$ & $238.915^{\star * *}$ \\
\hline Observation & 117 & 117 & 117 & 117 & 117 & 117 \\
\hline
\end{tabular}

Notes: z-statistics are in parentheses. ${ }^{*} 10 \%$ Significance level. ${ }^{*} 5 \%$ Significance level. ${ }^{* * *} 1 \%$ Significance level.

purpose. We find that for interest rate derivatives use for hedging and trading is significantly impacted by the variable LIQUID. LIQUID is not showing and significant relation for hedging derivatives use. This result weakly supports the argument related to ability of banks to reduce financial distress and hence reduces their expected cost. Credit risk is also an important factor for interest rate derivativesusage $e^{23}$. We find the moderate negative significant relationship of CREDIT_RISK ${ }^{24}$ with interest rate derivatives use for hedging and trading pur-

\footnotetext{
${ }^{23}$ Credit defaults may be driven by change in interest rates.

${ }^{24}$ Ratio of non performing loans to the total loans.
} 
pose. CREDIT_RISK is not showing any significant relationship with derivatives use except for model 1 . The results counter the argument that high credit risk is associated with higher probability of using derivatives. Capital adequacy ratio (CAR) is not showing and significant relationship with derivatives usage. But literature ${ }^{25}$ supports the fact that higher CAR indicates that banks are more capital constrained and assume the higher contingent risk. With high CAR, banks have the incentive to have the higher economic capital to offset contingent events. PROFITABILITY is showing a negative significant relationship with the use of derivatives for hedging and trading. ASSET_STRUCT_1 represents the leverage in banks' balance sheet. Leverage is not showing any significant relationship with interest rate derivatives usage. Similarly, ASSET_STRUCT_2 is also not showing any significant relation with derivatives usage. MARKET_CAP is showing a positive significant relation with interest rate derivatives usage for both hedging and hedging and trading cases. The results support the fact that higher market value of equity capital encourages the bank to use derivatives.

INT_RISK_2 represents the asset-liability mismatch risk and is showing a positive significant relation with derivatives usage for all model specifications. On the other hand, INT_RISK_1 is a proxy of market-related interest rate risk and is showing a negative relation with derivatives usage. This finding supports the arguments that banks are using interest rate derivatives to mitigate asset-liability mismatch risk and this information is absorbed by the market which in turn negatively impacts the market-related interest rate risk factor and its impact on derivatives usage. D_2008 and D_2009 are time dummies and are showing a significant positive relationship with derivatives usage for all model specifications. Constant represents the time effect of the year 2010. To capture the impact of control variables and interest rate risk variables on the likely impact of $1 \%$ change in interest rate on hedging interest rate derivatives and total interest rate derivatives. Similar models are used by the replacement of IRD_HEDGE by IRD_PV_HEDGE and IRD_TOTAL by IRD_PV_TOTAL ${ }^{26}$.

Table 10 reports the results of the likely impact of $1 \%$ change in interest rates on derivatives usage and how it is related to bank characteristics and interest rate risk variables using fixed effect Tobit models. The Chi-square statistics report the goodness of fit of models. The likely impact of $1 \%$ change in interest rate on derivatives is also showing significant and relationship with SIZE and CREDIT_ RISK and marginally negative relationship with ASSET_STRUCT_2 for derivatives usage for hedging purpose. But there is no relation to these variables for the case where derivatives are used for hedging and trading purposes. Capital adequacy ratio (CAR) is not showing and significant relationship with PV01 of derivatives usage for hedging purpose. But for hedging and trading purpose, PV01 is showing the positive significant relationship.INT_RISK_2 is not showing any impact on PV01 of derivatives usage. But INT_RISK_1 is showing marginal negative relationship on PV01.

\footnotetext{
${ }^{25}$ Nachane and Ghosh [10]

${ }^{26}$ See Appendix.
} 
Table 10. Empirical Estimation of likely impact of $1 \%$ change in interest rate on derivatives use: Tobit Fixed Effects Regression Model.

\begin{tabular}{|c|c|c|c|c|c|c|}
\hline & \multicolumn{3}{|c|}{ Hedging } & \multicolumn{3}{|c|}{ Hedging and Trading } \\
\hline & Model 1 & Model 2 & Model 3 & Model 1 & Model 2 & Model 3 \\
\hline \multirow[t]{2}{*}{ Constant } & $-0.00166^{* * *}$ & $-0.00232^{* * *}$ & $-0.00223^{* * *}$ & $-0.00247^{\star}$ & $-0.00293^{\star}$ & -0.00266 \\
\hline & $-(3.332)$ & $-(3.593)$ & $-(3.475)$ & $-(1.924)$ & $-(1.741)$ & $-(1.597)$ \\
\hline \multirow[t]{2}{*}{ 2008_DUM } & 0.00006 & 0.00008 & 0.00008 & -0.00013 & -0.00011 & -0.00013 \\
\hline & $(0.593)$ & $(0.842)$ & $(0.814)$ & $-(0.534)$ & $-(0.450)$ & $-(0.498)$ \\
\hline \multirow[t]{2}{*}{ 2009_DUM } & 0.00016 & $0.00020^{*}$ & $0.00019^{*}$ & -0.00015 & -0.00012 & -0.00014 \\
\hline & $(1.501)$ & $(1.843)$ & $(1.804)$ & $-(0.562)$ & $-(0.429)$ & $-(0.501)$ \\
\hline \multirow[t]{2}{*}{ SIZE } & $0.00016^{* * *}$ & $0.00023^{* * *}$ & $0.00022^{* * *}$ & 0.00013 & 0.00016 & 0.00015 \\
\hline & $(4.512)$ & $(3.918)$ & $(3.877)$ & $(1.424)$ & $(1.090)$ & $(1.012)$ \\
\hline \multirow[t]{2}{*}{ LIQUID } & -0.00007 & -0.00011 & -0.00002 & -0.00057 & -0.00081 & -0.00055 \\
\hline & $-(0.040)$ & $-(0.062)$ & $-(0.013)$ & $-(0.121)$ & $-(0.169)$ & $-(0.117)$ \\
\hline \multirow[t]{2}{*}{ CREDIT_RISK } & $0.02651^{* * *}$ & $0.02757^{* * *}$ & $0.02878^{\star * *}$ & -0.00884 & -0.01151 & -0.00807 \\
\hline & $(3.503)$ & $(3.559)$ & $(3.747)$ & $-(0.453)$ & $-(0.570)$ & $-(0.404)$ \\
\hline \multirow[t]{2}{*}{ CAR } & -0.00001 & -0.00002 & -0.00002 & $0.00014^{* * *}$ & $0.00014^{\star * *}$ & $0.00014^{* * *}$ \\
\hline & $-(0.693)$ & $-(0.782)$ & $-(0.888)$ & $(2.778)$ & $(2.793)$ & $(2.725)$ \\
\hline \multirow[t]{2}{*}{ PROFITABILITY } & 0.01964 & 0.01513 & 0.01871 & -0.00180 & -0.01226 & -0.00212 \\
\hline & $(1.535)$ & $(1.192)$ & $(1.473)$ & $-(0.055)$ & $-(0.370)$ & $-(0.064)$ \\
\hline \multirow[t]{2}{*}{ ASSET_STRUCT_1 } & 0.00003 & 0.00003 & 0.00003 & 0.00005 & 0.00005 & 0.00005 \\
\hline & $(1.079)$ & $(1.006)$ & $(1.032)$ & $(0.715)$ & $(0.682)$ & $(0.707)$ \\
\hline \multirow[t]{2}{*}{ ASSET_STRUCT_2 } & $-0.00003^{*}$ & $-0.00003^{\star}$ & $-0.00003^{*}$ & -0.00004 & -0.00004 & -0.00004 \\
\hline & $-(1.688)$ & $-(1.704)$ & $-(1.727)$ & $-(0.871)$ & $-(0.860)$ & $-(0.875)$ \\
\hline \multirow[t]{2}{*}{ MARKET_CAP } & -0.00006 & -0.00007 & -0.00009 & 0.00026 & 0.00031 & 0.00025 \\
\hline & $-(0.152)$ & $-(0.157)$ & $-(0.206)$ & $(0.240)$ & $(0.280)$ & $(0.233)$ \\
\hline \multirow[t]{2}{*}{ INT_RISK_1 } & $-0.00001^{*}$ & - & $-0.00001^{*}$ & $-0.00003^{*}$ & - & $-0.00003^{*}$ \\
\hline & $-(1.663)$ & - & $-(1.733)$ & $-(1.879)$ & - & $-(1.886)$ \\
\hline \multirow[t]{2}{*}{ INT_RISK_2 } & - & $3.37 \times 10^{-7}$ & $3.55 \times 10^{-7}$ & - & $6.92 \times 10^{-8}$ & $1.20 \times 10^{-7}$ \\
\hline & - & $(1.307)$ & $(1.394)$ & - & $(0.103)$ & $(0.182)$ \\
\hline Chi-Square statistics & $63.881^{\star \star \star}$ & $62.283^{\star \star \star}$ & $66.884^{\star * \star}$ & $29.199^{\star \star}$ & $24.927^{\star}$ & $29.240^{\star \star}$ \\
\hline Observation & 117 & 117 & 117 & 117 & 117 & 117 \\
\hline
\end{tabular}

Notes: $\mathrm{z}$-statistics are in parentheses. ${ }^{*} 10 \%$ Significance level. ${ }^{*} 5 \%$ Significance level. ${ }^{* * *} 1 \%$ Significance level.

\section{Conclusion}

In this study, using simulation and market interest rate sensitivity analysis, we examine the determinants of interest rate derivatives usage by all Indian commercial listed banks. Our results elucidate that in addition to bank-specific characteristics, interest rate risk does influence the derivatives usage by banks. Results show that bank size, MARKET_CAP and asset-liability mismatch (INT_RISK_2) are 
positively related to derivatives usage by banks. But Liquidity, credit risk in banks, profitability, and market sensitive interest rate risk is negatively related to derivatives usage. Further study can be conducted by including macroeconomic variables to examine the determinants of interest rate derivatives usage.

\section{References}

[1] Basel Committee on Banking Supervision (1999) Recommendation for Public Disclosure of Trading and Derivatives Activities of Banks and Securities Firms. Bank for International Settlements.

[2] Basel Committee on Banking Supervision (2001) Principles for the Management and Supervision of Interest Rate Risk. Bank for International Settlements.

[3] Flannery, M.J. and James, C.M. (1984) The Effect of Interest Rate Changes on the Common Stock Returns of Financial Institutions. The Journal of Finance, 39, 11411153. https://doi.org/10.1111/j.1540-6261.1984.tb03898.x

[4] Booth, J.R. and Officer, D.T. (1985) Expectations, Interest Rates, and Commercial Bank Stocks. The Journal of Financial Research, 8, 51-58.

https://doi.org/10.1111/j.1475-6803.1985.tb00425.x

[5] Choi, J.J, Elyasiani, E. and Kopecky, K.J. (1992) The Sensitivity of Bank Stock Returns to Market, Interest and Exchange Rate Risks. Journal of Banking and Finance, 16, 983-1004.

[6] Shanker, L. (1996) Derivatives Usage and Interest Rate Risk of Large Banking Firms. The Journal of Futures Markets, 16, 459-474. https://doi.org/10.1002/(SICI)1096-9934(199606)16:4<459::AID-FUT6>3.0.CO;2-H

[7] Patnaik, I. and Shah, A. (2003) Interest-Rate Risk in the Indian Banking System. ICRIER Working Paper No. 92, Indian Council for Research on International Economic Relations, New Delhi.

[8] Carter, D., Simpson, W. and Tandon, A. (April 2005) Managerial Ownership and Compensation and the Use of Interest-Rate Derivatives by US Banks. Working Paper, FMA Conference 2006, Salt Lake City.

[9] Purnanandam, A. (2007) Interest Rate Derivatives At Commercial Banks: An Empirical Investigation. Journal of Monetary Economics, 54, 1769-1808.

[10] Nachane, D.M. and Ghosh, S. (2007) An Empirical Analysis of the Off-Balance Sheet Activities of Indian Banks. Journal of Emerging Market Finance, 6, 39-59. https://doi.org/10.1177/097265270700600102

[11] Saha, A., Subramanian, V., Basu, S. and Mishra, A.K. (2007) Networth Exposure of Interest Rate Risk: An Empirical Analysis of Indian Commercial Banks. European Journal of Operational Research, 193, 581-590.

[12] Mian, S.L. (1996) Evidence on Corporate Hedging Policy. Journal of Financial and quantitative Analysis, 31, 419-439. https://doi.org/10.2307/2331399

[13] Colquitt, L.L. and Hoyt, R.E. (1997) Determinants of Corporate Hedging Behavior: Evidence from the Life Insurance Industry. Journal of Risk and Insurance, 64, 649-671. https://doi.org/10.2307/253890

[14] Sinkey, J.F. and Carter, D.A. (2001) Evidence on the Financial Characteristics of Banks That Do and Do Not Use Derivatives. The Quarterly Review of Economics and Finance, 40, 431-449.

[15] Cummins, J.D., Phillips, R.D. and Smith, S.D. (2001) Derivatives and Corporate Risk Management: Participation and Volume Decisions in the Insurance Industry. 
Journal of Risk and Insurance, 68, 51-91. https://doi.org/10.2307/2678132

[16] Shiu, Y.M. and Moles, P. (2010) What Motivates Banks to Use Derivatives: Evidence from Taiwan. The Journal of Derivatives, 17, 67-78.

https://doi.org/10.3905/jod.2010.17.4.067 


\section{Appendix}

Model 1 specification is given by:

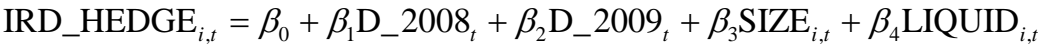

$$
\begin{aligned}
& +\beta_{5} \text { CREDIT_RISK }_{i, t}+\beta_{6} \text { CAR }_{i, t}+\beta_{7} \text { PROFITABILITY }_{i, t} \\
& +\beta_{8} \text { ASSET_STRUCT_ } 1_{i, t}+\beta_{9} \text { ASSET_STRUCT_ } 2_{i, t} \\
& +\beta_{10} \text { MARKET_CAP }+\beta_{11} \text { INT_RISK_ } 1_{i}+\varepsilon_{i, t}
\end{aligned}
$$

Model 2 specification is given by:

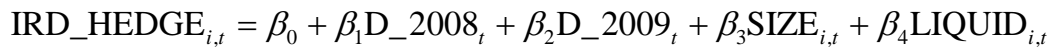

$$
\begin{aligned}
& +\beta_{5} \text { CREDIT_RISK }_{i, t}+\beta_{6} \text { CAR }_{i, t}+\beta_{7} \text { PROFITABILITY }_{i, t} \\
& +\beta_{8} \text { ASSET_STRUCT_ } 1_{i, t}+\beta_{9} \text { ASSET_STRUCT_ } 2_{i, t} \\
& +\beta_{10} \text { MARKET_CAP }+\beta_{12} \text { INT_RISK_ } 2_{i}+\varepsilon_{i, t}
\end{aligned}
$$

Model 3 specification is given by:

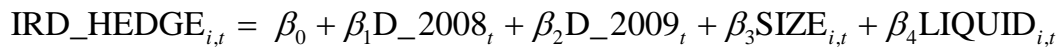

$$
\begin{aligned}
& +\beta_{5} \text { CREDIT_RISK }_{i, t}+\beta_{6} \mathrm{CAR}_{i, t}+\beta_{7} \text { PROFITABILITY }_{i, t} \\
& +\beta_{8} \text { ASSET_STRUCT_ } 1_{i, t}+\beta_{9} \text { ASSET_STRUCT_ }_{i, t} \\
& +\beta_{10} \text { MARKET_CAP }+\beta_{11} \text { INT_RISK_ } 1_{i} \\
& +\beta_{12} \text { INT_RISK_2 } i+\varepsilon_{i, t}
\end{aligned}
$$

Similarly for the motivation for total interest rate derivatives usage, the dependent variable for all models is IRD_TOTAL. Same explanatory variables are taken for total derivatives regression analysis.

Model 1 specification is given by:

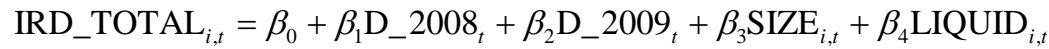

$$
\begin{aligned}
& +\beta_{5} \text { CREDIT_RISK }_{i, t}+\beta_{6} \text { CAR }_{i, t}+\beta_{7} \text { PROFITABILITY }_{i, t} \\
& +\beta_{8} \text { ASSET_STRUCT_ } 1_{i, t}+\beta_{9} \text { ASSET_STRUCT_ } 2_{i, t} \\
& +\beta_{10} \text { MARKET_CAP } i
\end{aligned}
$$

Model 2 specification is given by:

$$
\begin{aligned}
& \mathrm{IRD} \_T O T A L_{i, t}=\beta_{0}+\beta_{1} \mathrm{D} \_2008_{t}+\beta_{2} \mathrm{D} \_2009_{t}+\beta_{3} \mathrm{SIZE}_{i, t}+\beta_{4} \mathrm{LIQUID}_{i, t} \\
& +\beta_{5} \text { CREDIT_RISK }_{i, t}+\beta_{6} \text { CAR }_{i, t}+\beta_{7} \text { PROFITABILITY }_{i, t} \\
& +\beta_{8} \text { ASSET_STRUCT_ } 1_{i, t}+\beta_{9} \text { ASSET_STRUCT_ } 2_{i, t} \\
& +\beta_{10} \text { MARKET_CAP }_{i}+\beta_{12} \text { INT_RISK_ } 2_{i}+\varepsilon_{i, t}
\end{aligned}
$$

Model 3 specification is given by:

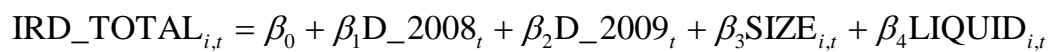

$$
\begin{aligned}
& +\beta_{5} \text { CREDIT_RISK }_{i, t}+\beta_{6} \text { CAR }_{i, t}+\beta_{7} \text { PROFITABILITY }_{i, t} \\
& +\beta_{8} \text { ASSET_STRUCT_ } 1_{i, t}+\beta_{9} \text { ASSET_STRUCT_ } 2_{i, t} \\
& +\beta_{10} \text { MARKET_CAP }+\beta_{11} \text { INT_RISK_1 } 1_{i} \\
& +\beta_{12} \text { INT_RISK_ } 2_{i}+\varepsilon_{i, t}
\end{aligned}
$$


Submit or recommend next manuscript to SCIRP and we will provide best service for you:

Accepting pre-submission inquiries through Email, Facebook, LinkedIn, Twitter, etc. A wide selection of journals (inclusive of 9 subjects, more than 200 journals)

Providing 24-hour high-quality service

User-friendly online submission system

Fair and swift peer-review system

Efficient typesetting and proofreading procedure

Display of the result of downloads and visits, as well as the number of cited articles Maximum dissemination of your research work

Submit your manuscript at: http://papersubmission.scirp.org/

Or contact tel@scirp.org 